\title{
PENGARUH PEMBERIAN EKSTRAK BIJI GANITRI (Elaeocarpus sphaericus Schum.) TERHADAP PENURUNAN KADAR KOLESTEROL MENCIT (Mus musculus) JANTAN PENDERITA DIABETES
}

\author{
Dianing Pawestri, Tristi Indah D.K., Hasyim As'ari \\ Program Studi Biologi, Fakultas Matematika dan Ilmu Pengetahuan Alam \\ Universitas PGRI Banyuwangi \\ Email:ian.noona7@gmail.com
}

\begin{abstract}
ABSTRAK
Hiperkolesterolemia sering dijumpai pada penderita diabetes mellitus, hal ini dikarenakan resistensi insulin pada diabetes mellitus meningkatkan lipolisis pada jaringan adiposa sehingga terjadi peningkatan lemak dalam darah termasuk kolesterol dan trigliserida, sehingga apabila kadar kolesterol tinggi dalam tubuh, maka dapat memicu berbagai penyakit (komplikasi) seperti penyakit jantung koroner, strok, dan ginjal. Oleh karena itu perlu dikembangkan alternatif pengobatan dengan menggunakan bahan alami yang diharapkan lebih efektif dan efisien. Biji ganitri (Elaeocarpus sphaericus Schum.) adalah salah satu alternatif bahan alami yang memiliki kandungan antioksida karena mengandung senyawa metabolit sekunder seperti flavonoid, glikosida, steroid, alkaloid, saponin, dan tanin. Penelitian ini bertujuan untuk mengetahui pengaruh pemberian ekstrak biji ganitri (Elaeocarpus sphaericus Schum.) terhadap penurunan kadar kolesterol mencit (Mus musculus) jantan penderita diabetes dengan metode sondase lambung dengan kontrol positif glibenklamid dan kontrol negatif aquades steril. Pada uji pengaruh pemberian ekstrak biji ganitri (Elaeocarpus sphaericus Schum.) terhadap penurunan kadar kolesterol mencit, dosis ekstrak biji ganitri yang digunakan $650 \mathrm{mg} / \mathrm{kgBB}, 1300 \mathrm{mg} / \mathrm{kgBB}$ dan $2600 \mathrm{mg} / \mathrm{kgBB}$. Hasil uji ANOVA menunjukkan bahwa nilai signifikasi sebesar $0,000(\mathrm{P}<0,05)$, Karena nilai $\mathrm{P}<0,05$ maka dapat disimpulkan bahwa terdapat perbedaan yang nyata dari masing-masing perlakuan dosis terhadap penurunan kadar kolesterol mencit. Hasil uji Duncan menunjukkan ekstrak biji ganitri (Elaeocarpus sphaericus Schum.) berpengaruh efektif pada pengobatan hari ke-25 yang terdapat pada perlakuan P3 yang menggunakan biji ganitri dengan dosis $2600 \mathrm{mg} / \mathrm{kgBB}$ yaitu dengan hasil kadar kolesterol 84,00 mg/dL.
\end{abstract}

Kata kunci: Hiperkolesterolemia, Diabetes mellitus, Biji ganitri, Ekstrak.

\begin{abstract}
Hypercholesterolemia is common in people with diabetes mellitus, this is because resistance in diabetes mellitus increases lipolysis in adipose tissue so there is an increase in blood fast including cholesterol an triglycerides, so if high cholesterol levels in the body it can trigger various diseases such as coronary heart disease, stroke and kidney. Therefore it is necessary to develop alternative treatment by using natural materials that are expected to be more effective and efficient. Ingredients that contain antioxidants because they contain secondary metabolite compounds as flavonoids, glycosides, steroids, alkaloids, saponins, and tannins. This study aims to determine the effect of granting ganitri seed extract (Elaeocarpus sphaericus schum) to decrease in cholesterol levels mice (Mus musculus) male with diabetes by gastricc sondase method with positive control glibenclamide and negative control of sterile


aquades. On test the effect of granting ganitri seed extract (Elaeocarpus sphaericus schum) to decrease in cholesterol levels mice, dosage of ganitri seed extract used $650 \mathrm{mg} / \mathrm{kgBB}, 1300 \mathrm{mg} / \mathrm{kgBB}$ and $2600 \mathrm{mg} / \mathrm{kgBB}$. ANOVA test results indicate that the value of significance of $0,000(\mathrm{P}<0,05)$, because of the value $\mathrm{P}<0,05$ so it can be concluded that there is a significant difference of each treatment dose to decrease mice cholesterol level. Showed ganitri seed (Elaeocarpus sphaericus schum) extract effective on the treathment day of 25 found in treatment $\mathrm{P} 3$ using ganitri seed with dose $2600 \mathrm{mg} / \mathrm{kgBB}$ namely with the results of cholesterol levels $84,00 \mathrm{mg} / \mathrm{dL}$.

Keywords: Hypercholesterolemia, Diabetes mellitus, Ganitri seed, Extract.

\section{PENDAHULUAN}

Di Indonesia diabetes mellitus merupakan salah satu masalah kesehatan yang besar. Diabetes mellitus tipe 2 adalah penyakit gangguan metabolik yang ditandai oleh kenaikan gula darah akibat penurunan sekresi insulin oleh pankreas atau gangguan fungsi insulin (Depkes, 2005). Menurut Koestadi (1989), penderita diabetes mellitus memiliki kecenderungan mengidap hiperkolesterolemia. Menurut Stapleton (2010) hiperkolesterolemia yaitukadar kolesterol plasma yang melebihi ambang batas normal, faktor resiko yang kuat dari penyakit kardiovaskular seperti jantung koroner. Menurut Sirregar (2010) juga mengatakan bahwa pada penderita diabetes mellitus tipe 2 terjadi kelainan metabolisme karena resistensi insulin yang mempengaruhi metabolisme dalam tubuh diantaranya terjadi perubahan proses produksi dan pembuangan lipoprotein plasma. Resistensi insulin pada diabetes mellitus tipe 2 meningkatkan lipolisis pada jaringan adiposa sehingga terjadi peningkatan lemak dalam darah termasuk kolesterol dan trigliserida (Rader, dkk. 2005).

Kolesterol adalah bagian dari lemak, zat ini merupakan salah satu dari komponen lemak itu sendiri. Kehadiran lemak sendiri dalam tubuh kita sesungguhnya memiliki fungsi sebagai zat gizi yang sangat diperlukan oleh tubuh disamping zat gizi lainnya seperti karbohidrat, protein, vitamin, dan mineral (Pellizzon, 2008). Pada manusia, Kadar kolesterol total dinyatakan tinggi apabila mencapai nilai $240 \mathrm{mg} / \mathrm{dL}$ atau lebih (Jellinger, 2012). Menurut Polychronopoulos dkk (2005) menyatakan bahwa, pada hewan perlakuan yaitu mencit (Mus musculus) memiliki nilai kolesterol total normal yaitu 26-82 $\mathrm{mg} / \mathrm{dL}$, maka diatas angka tersebut dapat dikatakan hiperkolesterolemia yaitu kadar kolesterol plasma yang melebihi ambang batas 
normal.

Penggunaan tanaman sekitar sebagai obat tradisonal untuk mengobati suatu penyakit merupakan pilihan yang sangat tepat. Penggunaan obat tradisional merupakan budaya masyarakat di berbagai belahan dunia (Khanna, dkk.2001). Tanaman yang berpotensi sebagai obat alami serta dimanfaatkan sebagai alternatif pengobatan adalah biji tanaman ganitri (Elaeocarpus sphaericus Schum.) Kumar, dkk. (2012). Biji ganitri memiliki kandungan senyawa metabolit sekunder seperti alkaloid, flavonoid, tannin, steroid, terpenoid atau saponin, dan glikosida Singh, dkk. (2000). Hal ini dilaporkan bahwa senyawa seperti flavonoid, polifenol, biflavonoid, tannin dan fenolik memiliki kapasitas antioksidan yang tinggi (Kumar, dkk 2008). Menurut Sargowo (2005) senyawa antioksidan memiliki kemampuan untuk menurunkan kolesterol yang berpotensi menyumbat pembuluh darah, senyawa antioksidan juga akan mencegah kerusakan sel-sel atau jaringan pembuluh darah.

Penelitian sebelumnya yang dilakukan Kumar, dkk (2008) menunjukkan bahwa ekstrak ganitri membuktikan adanya aktivitas antioksida yang mencegah kerusakan hati dan menghambat pembentukan peroksida lipid.

Mekanisme antioksidan dalam proses hambatan tersebut yaitu dengan cara mengoksidasikan senyawa-senyawa yang ada dalam antioksidan sehingga sel-sel dalam tubuh bisa terlindungi dari radikal bebas yang menyebabkan peroksida lipid. Hal ini sesuai dengan pernyataan Kaur dan Mondal (2014) bahwa, flavonoid mampu menghambat reaksi oksidasi dari kolesterol LDL, melalui hambatan ini maka penurunan kadar kolesterol akan terjadi.

Berdasarkan uraian di atas, dapat diketahui potensi biji ganitri sebagai pengobatan untuk penurunan kadar kolesterol darah, maka peneliti tertarik untuk meneliti tentang "Pengaruh Pemberian Ekstrak Biji Ganitri (Elaeocarpus sphaericus Schum) terhadap Penurunan Kadar Kolestrol Mencit (Mus musculus) Jantan Penderita Diabetes". 


\section{METODE PENELITIAN}

Penelitian ini merupakan penelitian eksperimental laboratoris. Penelitian Pengaruh Pemberian Ekstrak Biji Ganitri (Elaeocarpus sphaericus Schum.) Terhadap Penurunan Kadar Kolesterol Mencit (Mus musculus) Jantan Penderita Diabetes dengan menggunakan metode sondase lambung.Rancangan penelitian ini menggunakan Rancangan Acak Lengkap (RAL). Pengukuran kadar kolesterol dilakukan sebelum dan sesudah injeksi aloksan. Penelitian ini menggunakan 25 ekor mencit (Mus musculus) jantan dengan berat badan \pm 25 gram berumur 2-3 bulan yang dibagi menjadi 5 kelompok dengan dosis ekstrak biji ganitri (Elaeocarpus sphaericus Schum.) yang berbeda yaitu $650 \mathrm{mg} / \mathrm{kg} \mathrm{BB}, 1300 \mathrm{mg} / \mathrm{kg} \mathrm{BB}$ dan $2600 \mathrm{mg} / \mathrm{kg} \mathrm{BB}$, sebagai kontrol positif $(\mathrm{K}+)$ menggunakan glibenklamid $0,013 \mathrm{mg} / \mathrm{kg}$ BB dan sebagai kontrol negatif (K-) menggunakan aquades. Setiap sediaan diberi secara sondase satu kali sehari selama 15 hari berturut-turut.

Berikut adalah rumus volume pemberian ekstrak biji ganitri sesuai dengan dosis adalah:

$$
\begin{aligned}
& \mathrm{P} 1=\frac{650 \mathrm{mg}}{1000 \mathrm{~g}} \times 25 \mathrm{~g}=16,25 \mathrm{mg} \\
& \mathrm{P} 2=\frac{1300 \mathrm{mg}}{1000 \mathrm{~g}} \times 25 \mathrm{~g}=32,5 \mathrm{mg} \\
& \mathrm{P} 3=\frac{2600 \mathrm{mg}}{1000 \mathrm{~g}} \times 25 \mathrm{~g}=65 \mathrm{mg}
\end{aligned}
$$

Keterangan :

P1, P2, P3 : Perlakuan 1, 2, 3

650, 1300, 2600 : Dosis yang diberikan

$1000 \mathrm{~g} \quad$ : Berat badan manusia $1 \mathrm{~kg}$

$25 \mathrm{~g} \quad$ : Berat badan mencit

Data hasil pengamatan dianalisis secara statistik dengan menggunakan uji Anova pada tingkat kepercayaan 95\%, dilanjutkan dengan uji Duncan untuk melihat perbedaan antar kelompok perlakuan. Analisis ststistik yang digunakan adalah program SPSS versi 17. 


\section{HASIL DAN PEMBAHASAN}

Tanaman ganitri (Elaeocarpus sphaericus Schum) yaitu salah satu tanaman yang habitat aslinya berasal dari daerah subtropis, jenis ini umumnya tumbuh pada ketinggian $1.200 \mathrm{~m}$ dpl (Safitri, 2011). Menurut para dokter Ayurvedik india ganitri dimanfaatkan sebagai obat potensial. kandungan senyawa metabolit sekunder seperti alkaloid, flavonoid, tannin, steroid, saponin, terpenoid, dan glikosida pada biji ganitri memiliki antioksidan yang tinggi. Senyawa antioksidan sendiri memiliki kemampuan untuk menurunkan kolesterol (Sargowo, 2005). Hasil penelitian dapat dilihat pada Tabel yang akan diuraikan berikut ini.

Tabel 1 Hasil Pengukuran Kadar Gula Darah Mencit (Mus musculus) Awal hari ke-7, dan hari ke-10.

$\begin{array}{lll}\text { Perlakuan } & \begin{array}{c}\text { hari ke-7 } \\ (\mathrm{mg} / \mathrm{dL})\end{array} & \begin{array}{l}\text { hari ke-10 } \\ (\mathrm{mg} / \mathrm{dL})\end{array} \\ \mathrm{P} 1 & 122,40 & 262,00 \\ \mathrm{P} 2 & 123,20 & 265,20 \\ \mathrm{P} 3 & 119,80 & 259,00 \\ \mathrm{~K}(-) & 121,20 & 263,40 \\ \mathrm{~K}(+) & 124,60 & 267,00 \\ \text { Keterangan : } & & \\ \text { P1 } & \text { : perlakuan dengan pemberian dosis ekstrak biji ganitri 650 } \mathrm{mg} / \mathrm{kgBB} \\ \text { P2 } & \text { : perlakuan dengan pemberian dosis ekstrak biji ganitri 1300mg/kgBB } \\ \text { P3 } & \text { : perlakuan dengan pemberian dosis ekstrak biji ganitri 2600mg/kgBB } \\ \text { K(-) } & \text { : kontrol negatif dengan pemberian aquades steril } \\ \text { K(+) } & \text { : kontrol positif dengan pemberian glibenklamid } \\ \text { Hari ke-7 } & \text { : setelah tahap aklimasi } \\ \text { Hari ke-10 } & \text { : setelah induksi aloksan }\end{array}$

Berdasarkan Tabel 1 pada pengukuran kadar gula darah dapat diketahui bahwa pada tahap aklimasi yaitu hari ke-7, keadaan gula darah mencit masih normal yaitu dengan rata-rata $122,24 \mathrm{mg} / \mathrm{dL}$. Kemudian pada hari ke-8 dilakukan induksi aloksan $210 \mathrm{mg} / \mathrm{kgBB}$ agar kadar gula darah mencit meningkat. Pada hari ke-10 setelah 
induksi aloksan keadaan gula darah mencit pada kelompok P1 mengalami peningkatan sebesar 53\%, pada P2 mengalami peningkatan sebesar 53\%, dan pada P3 mengalami peningkatan gula darah sebesar 54\%. Sedangkan pada kelompok Kmengalami peningkatan kadar gula darah sebesar 54\% dan kelompok K+ mengalami peningkatan gula darah sebesar 53\%. Dari keadaan gula darah yang mengalami peningkatan tersebut dikarenakan hormon insulin tidak dapat bekerja dengan baik, sehingga mencit dikatakan hiperglikemia. Hal ini sesuai dengan pernyataan Rohilla, dkk (2012) bahwa, aloksan secara selektif merusak $\beta$ pangkreas dengan cara memecah ikatan DNA pada sel $\beta$ pangkreas, hal ini menyebabkan sel $\beta$ pangkreas tidak dapat memproduksi hormon insulin.

Tabel 2 Hasil Pengukuran Kadar Kolesterol Darah Mencit (Mus musculus) Awal hari ke-7, induksi aloksan hari ke-10 dan pengobatan hari ke-17 dan ke-25.

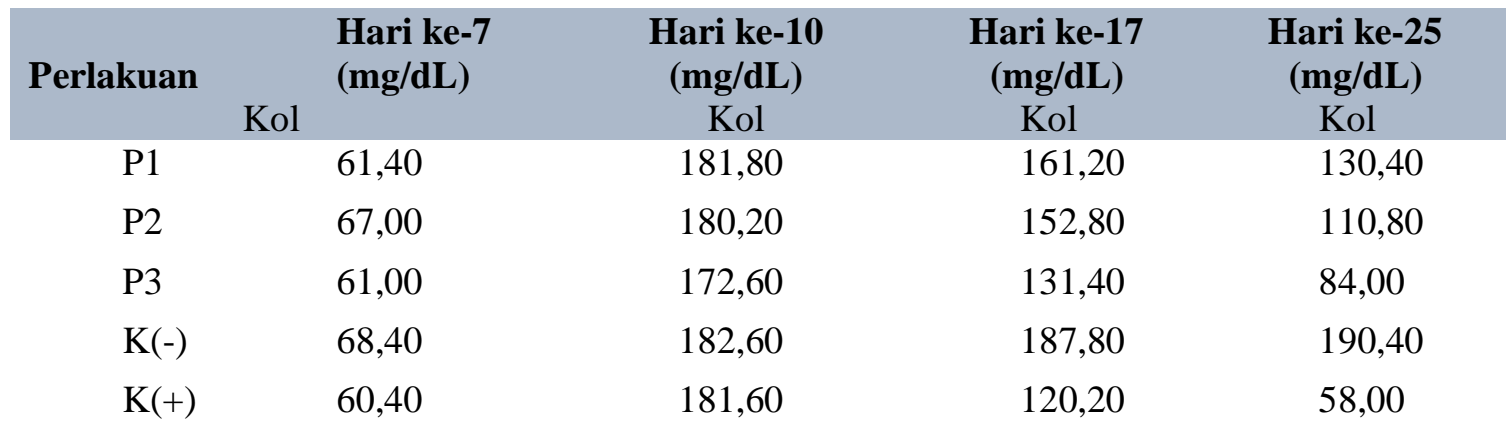

Keterangan :

P1 :perlakuan dengan pemberian dosis ekstrak biji ganitri $650 \mathrm{mg} / \mathrm{kgBB}$

P2 :perlakuan dengan pemberian dosis ekstrak biji ganitri 1300mg/kgBB

P3 :perlakuan dengan pemberian dosis ekstrak biji ganitri 2600mg/kgBB

$\mathrm{K}(-) \quad$ :kontrol negatif dengan pemberian aquades steril

$\mathrm{K}(+)$ :kontrol positif dengan pemberian dosis glibenklamid

Hari ke-7 : setelah aklimasi

Hari ke-10 : setelah induksi aloksan

Hari ke-17 : induksi ekstrak biji ganitri

Hari ke-25 : induksi ekstrak biji ganitri 
Berdasarkan data yang ditunjukkan pada Tabel 2 yaitu pengukuran kadar kolesterol darah, dapat diketahui bahwa pada masing-masing perlakuan memiliki hasil yang berbeda. Hasil pengukuran kadar kolesterol darah semua mencit pada tahap aklimasi yaitu hari ke-7 masih dalam keadaan normal yang memiliki nilai ratarata $63,64 \mathrm{mg} / \mathrm{dL}$, yang mana kadar kolesterol darah hewan perlakuan yaitu mencit (Mus musculus) memiliki nilai kolesterol total normal 26-82 mg/dL, jika diatas angka tersebut dapat dikatakan hiperkolesterolemia yaitu kadar kolesterol plasma yang melebihi ambang batas normal (Polychronopoulos, dkk, 2005). Sehingga dalam percobaan ini dilakukan induksi aloksan pada hari ke-10 dengan tujuan untuk meningkatkan kadar gula darah dengan harapan kadar kolesterol darah juga ikut meningkat. Pada hari ke-10 menunjukkan adanya rata-rata peningkatan pada hasil pengukuran kadar kolesterol darah mencit yaitu sebesar 64\%. Hal ini sesuai dengan pernyataan Rader, dkk (2005) bahwa, pada penderita diabetes mellitus karena resistensi insulin yang mempengaruhi metabolisme dalam tubuh diantaranya terjadi perubahan proses produksi, sehingga resistensi insulin pada diabetes mellitus dapat meningkatkan lipolisis pada jaringan adiposa sehingga terjadi peningkatan lemak dalam darah termasuk kolesterol.

Berdasarkan hasil penelitian yang ditunjukkan pada Tabel 2 bahwa pemberian ekstrak biji ganitri berpengaruh dalam menurunkan kadar kolesterol darah mencit. Pada hasil perlakuan hari ke-17 menunjukkan bahwa penurunan kadar kolesterol pada kelompok P1 sebesar 11\%, pada kelompok P2 mengalami penurunan sebesar 15\%, pada kelompok P3 mengalami penurunan sebesar 24\% dan pada kelompok $\mathrm{K}+$ mengalami penurunan sebesar $34 \%$, sedangkan pada kelompok K- mengalami kenaikan kadar kolesterol sebesar 3\%. Hal ini dikarenakan pada kelompok K- tidak diberikan perlakuan khusus seperti pada kelompok perlakuan P1, P2, P3, dan K+, melainkan hanya diberikan aquades steril yang tidak memiliki aktivitas dalam menurunkan kadar kolesterol darah. 
Berdasarkan hasil perlakuan hari ke-25 menunjukkan bahwa penurunan kadar kolesterol pada kelompok P1 sebesar 28\%, pada kelompok P2 mengalami penurunan sebesar 38\%, pada kelompok P3 mengalami penurunan sebesar 51\% dan pada kelompok $\mathrm{K}+$ mengalami penurunan sebesar 68\%, sedangkan pada kelompok Kmengalami kenaikan kadar kolesterol sebanyak 4\%. Hal ini dikarenakan padakelompok K- tidak diberikan perlakuan khusus seperti pada kelompok perlakuan P1, P2, P3, dan $\mathrm{K}+$, melainkan hanya diberikan aquades steril yang tidak memiliki aktivitas dalam menurunkan kadar kolesterol darah.

Hasil perlakuan pada hari ke-17 dan hari ke-25 menunjukkan penurunan kadar kolesterol yaitu pada kelompok P3 yang menggunakan dosis ekstrak biji ganitri $2600 \mathrm{mg} / \mathrm{kgBB}$, pada hari ke-17 dengan persentase sebesar $24 \%$ dan hari ke-25 dengan persentase sebesar 51\%. Hal ini dikarenakan pada dosis tersebut memiliki aktivitas penurunan kadar kolesterol yang baik dibandingkan dengan kelompok P1 dan P2 yang menggunakan dosis ekstrak biji ganitri pada P1 $(650 \mathrm{mg} / \mathrm{kgBB})$ dan P2 menggunakan dosis ekstrak biji ganitri (1300mg/kgBB), selain itu pada kelompok P3 juga hampir mampu menyamai dosis obat oral glibenklamid yang diberikan pada kelompok perlakuan $\mathrm{K}+$ yang memiliki hasil kadar kolesterol yang rendah, yang mana glibenklamid merupakan obat antidiabetes oral. Hasil ini menunjukkan bahwa peningkatan dosis ekstrak biji ganitri sebanding dengan kemampuannya dalam penurunan kadar kolesterol darah sehingga hampir setara dengan dosis obat oral glibenklamid. Hal ini dikarenakan pada dosis yang diberikan pada kelompok P3 yaitu 2600mg/kgBB memiliki kandungan antioksidan yang lebih tinggi dibandingkan dengan dosis P1 dan P2, sehingga dengan banyaknya kandungan antioksidan di dalam biji ganitri yang berupa senyawa flavonoid maka mampu untuk menghambat oksidasi kolesterol karena radikal bebas dalam tubuh dengan cara mengoksidasikan senyawa-senyawa yang ada dalam antioksidan, sehingga sel-sel dalam tubuh bisa terlindungi dari radikal bebas. Hal ini sesuai dengan pernyataan Kaur dan Mondal (2014) bahwa, flavonoid mampu menghambat reaksi oksidasi dari kolesterol LDL, 
melalui hambatan ini maka penurunan kadar kolesterol akan terjadi. Berikut adalah skema cara kerja antioksidan dalam menangkal radikal bebas dalam tubuh.

Tabel 3 Hasil Pengukuran Berat Badan Mencit (Mus musculus) Jantan pada MasingMasing Tahap Perlakuan

$\begin{array}{lcccc}\text { Perlakuan } & \text { Hari ke-7 } & \begin{array}{c}\text { Hari ke-10 } \\ (\mathrm{g})\end{array} & \begin{array}{c}\text { Hari ke-17 } \\ (\mathrm{g})\end{array} & \begin{array}{c}\text { Hari ke-25 } \\ (\mathrm{g})\end{array} \\ \text { P1 } & (\mathrm{g}) & 20,20 & 22,60 & 23,60 \\ \text { P2 } & 25,40 & 20,00 & 24,00 & 24,60 \\ \text { P3 } & 25,00 & 20,00 & 24,80 & 26,00 \\ \text { K(-) } & 25,20 & 20,80 & 21,00 & 18,00 \\ \text { K(+) } & 25,40 & 20,60 & 25,80 & 27,80 \\ \text { Keterangan : } & 25,00 & 20,40 & & \end{array}$

P1 :perlakuan dengan pemberian dosis ekstrak biji ganitri $650 \mathrm{mg} / \mathrm{kgBB}$

P2 :perlakuan dengan pemberian dosis ekstrak biji ganitri 1300mg/kgBB

P3 :perlakuan dengan pemberian dosis ekstrak biji ganitri 2600mg/kgBB

$\mathrm{K}(-) \quad$ :kontrol negatif dengan pemberian aquades steril

$\mathrm{K}(+)$ :kontrol positif dengan pemberian dosis glibenklamid

Hari ke-7 : setelah aklimasi

Hari ke-10 : setelah induksi aloksan

Hari ke-17 : induksi ekstrak biji ganitri

Hari ke-25 : induksi ekstrak biji ganitri

Berdasarkan Tabel 3 hasil pengukuran berat badan mencit yang dilakukan menunjukkan bahwa pada saat sesudah aklimasi hari ke-7 berat badan mencit masih normal yaitu dengan rata-rata 25,20 gram, sedangkan pada saat sesudah induksi aloksan hari ke-10 berat badan mencit menurun sebesar 19\% dengan rata-rata 20,40 gram, berat badan mencit menurun pada saat setelah induksi aloksan dikarenakan mencit menderita diabetes. Pada saat diabetes akan terjadi kelainan metabolisme karena resistensi insulin yang mempengaruhi metabolisme dalam tubuh diantaranya glukosa darah tidak dapat masuk ke dalam sel otot dan jaringan lemak sehingga untuk 
memperoleh sumber energi untuk kelangsungan fungsinya, maka otot dan jaringan lemak akan memecahkan cadangan energi yang terdapat dalam dirinya sendiri melalui proses lipolisis. Proses lipolisis yang berlangsung terus-menerus pada akhirnya menyebabkan massa otot berkurang dan terjadilah penurunan berat badan (Ashaeryanto, dkk 2011).

Pemberian ekstrak biji ganitri pada berat badan mencit juga berpengaruh, yang ditunjukkan pada Tabel 3 yaitu pada hari ke-17 dan hari ke-25 berat badan mencit berangsur naik yaitu pada hari ke-17 berat badan mencit tertinggi terdapat pada kelompok P2 dengan nilai persentase sebesar 20\% dan berat badan terkecil terdapat pada kelompok P1 dengan nilai persentase sebesar 12\%, sedangkan pada hari ke-25 berat badan mencit tertinggi terdapat pada kelompok P3 dengan nilai persentase sebesar $25 \%$ dan berat badan terkecil terdapat pada kelompok P1 dengan nilai persentase sebesar 17\%. Hal ini dikarenakan kandungan antioksidan dalam biji ganitri mampu bekerja dalam menghambat peroksida lipid dan menstabilkan kembali kerja metabolisme dalam tubuh, sehingga berat badan mencit berangsur normal dan kolesterol mencit juga normal kembali.

\section{KESIMPULAN DAN SARAN}

\subsection{Kesimpulan}

Terdapat pengaruh ekstrak biji ganitri (Elaeocarpus sphaericus Schum.) terhadap penurunan kadar kolesterol mencit (Mus musculus) jantan penderita diabetes. Yang mana penurunan terbesar ditunjukkan pada kelompok P3 dengan rata-rata 84,00 $\mathrm{mg} / \mathrm{dL}$, sedangkan penurunan terendah ditunjukkan pada kelompom P1 dengan ratarata $130,40 \mathrm{mg} / \mathrm{dL}$. Sedangkan dosis yang efektif pada ekstrak biji ganitri (Elaeocarpus sphaericus Schum.) yaitu pada dosis $2600 \mathrm{mg} / \mathrm{kgBB}$.

\section{REFERENSI}

Ashaeryanto, Tiara, I.M, Diana, K. 2011. Berat Badan Menurun. Modul Tutor. Blok Endokrin dan Metabolisme: FK Universitas Haluoelo Kendari.

Departemen Kesehatan. 2005. Pharmaceutical Care untuk Penyakit Diabetes Melitus.

Jellinger PS, Smith DA, Mehta AE, Ganda O, Handelsman Y, Rodbard HW, et al. Guidelines for Management of Dyslipidemia and Prevention of Atherosclerosis. 
AACE Lipid And Atherosclerosis Guidelines, Endocr Pract. 2012.18: 10.

Kaur S, Mondal P, 2014, "Study of Total Phenolic and Flavonoid Content, Antioxidant Activity and Antimicrobial Properties of Medicinal Plants Citation”, J Microbiol.

Khanna A.K., F. Rizfi and R. Chander 2001. Lipid Lowering Activity of Phyllanthus Niruriin Hiperlipidemic Rats. Journal of Ethnopharmacology 82 (1): 19-22.

Koestadi, 1989. Kimia Klinik Teori dan Praktek Darah. AAK Bhakti Wiyata. Kediri.

Kumar, Sarvana. Manfaat Pengobatan Rudraksha (Ganitri). Majalah Kesehatan. 2 Juni 2012. [Diakses 3 April 2017].

Kumar ST, dkk, 2008 Evaluation of Antioxidant Properties of Elaeocarpus ganitrus Roxb. Leaves.Iranian journal ofPharmaceutical Research; 7 (3): 211-215.

Pellizzon MA. Diet Induced Atherosclerosis/Hypercholesterolemia In Rodent Models.Brief scientific Literature Review. Oktober 2008.

Polychronopoulos, Evangelos, Panagiotakos, Demosthenes B dan Polystipioti, Anna. Diet, Lifestyle Factors \& Hypercholesterolemia In Eldery Men \& Women From Cyprus. 2005. Journal fo Lipids Health Disease 4;7.

Rader DJ, Hoobs HH. Disorders of lipoprotein metabolism. Dalam: Harrison's Principles of Internal Medicine. Edisi ke-16. New York: Mc Graw Hill; 2005. 2286-98.

Rohilla, A. \& Shahjad Ali. 2012. Alloxan Induced Diabetes: Mechanisms and Effects.International Journal of Research in Pharmaceutical and Biomedical Sciences, 3 (2): 819-823.

Safitri. 2011. Jenis Komersial yang Belum Banyak Dilirik Usahawan. www.asianherbalshow.com.2011/06/1. Jakarta. [Diakses 4 April 2016].

Sargowo, Djanggan. 2005. Peranan Kadar Trigliserida dan Lippoprotein sebagai factor Resiko Penyakit Jantung Koroner(Studi Pendahuluan). Jurnal Saintika.Lembaga Penelitian Universitas Brawijaya-Malang. Vol 13 no. 2.

Siregar J. Perbandingan kadar LDL kolesterol pada Diabetes Mellitus dengan atau tanpa hipertensi. (tesis). Medan: Universitas Sumatera Utara; 2010.16-7.

Stapleton PA, Goodwill AG, James ME, Brock RW, Frisbee JC. Hypercholesterolemia and microvascular dysfunction: interventional strategies. J Inflamm (Lond) 2010.7: 54 